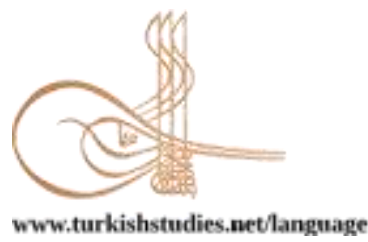

Turkish Studies - Language and Literature

eISSN: 2667-5641

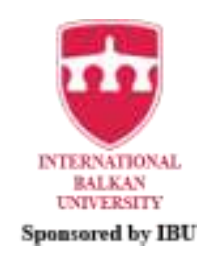

Research Article / Araştırma Makalesi

\title{
Ana Dili Kürtçe Olan Öğrencilerin Rusçayı İkinci Yabancı Dil Olarak Öğrenmeleri Üzerine Yapılan Anket Sonuçlarının Analizi: Van Yüzüncü Yıl Üniversitesi Van MYO Turizm ve Otel İşletmeciliği ile Turizm Rehberliği Programları Örneği
}

\author{
Analysis of the Results of the Survey Conducted on Students Who Learn Russian as A Second \\ Foreign Language and Whose Mother Tongue is Kurdish: Van Yüzüncü Yıl Unıversity Van \\ Vocational School of Tourism-Hotel Management and Tourism Guidance Programmes Example
}

\author{
Nükhet Eltut Kalender*
}

\begin{abstract}
Kurdish is a widely spoken language spoken in the province of Van, like other cities in eastern region of Turkey. Kurdish has a number of dialects such as Kurmanji, Sorani, Luri, Gorani, Zazaki (Kırdki). Native speakers of Kurdish who lives in Van speaks Kurmanji dialect of Kurdish as their mother tongue. Therefore, there are a significant number native-speaker students of Kurdish at Van Yüzüncü Y1l University ${ }^{1}$. Russian as a second foreign language became an elective beginning from the 2013-2014 academic year fall term in Van Vocational High School of Tourism-Hotel Management and Tourism Guidance Programmes. It is seen that as a result of they interrelated Russian and their native language Kurdish in terms of pronunciation, stress, intonation, word and sentence structure similarities, the native-speaker students of Kurdish who study at the relevant programmes developed different learning techniques compared to other students who aren't native speakers of Kurdish. As a result of this, it became necessary to implement a survey questionnaire and study this situation. This study came out of the review of the data which were collected from the questionnaire applied to the students at relevant programmes during 2015-2016 academic year and analyzed on SPSS.
\end{abstract}

\section{Structured Abstract : Introduction}

Foreign language education in Turkey starts with English at primary school second grade and continues during the rest of school life. However, in some educational institutions individuals are free to choose additional elective second foreign language options in addition to compulsory English education.

\footnotetext{
* Dr.Öğr. Üyesi, Van Yüzüncü Yıl Üniversitesi, Edebiyat Fakültesi, Doğu Dilleri ve Edebiyatları Bölümü, Rus Dili ve Edebiyat1 ABD.

Asst. Prof., Van Yüzüncü Yll University, Faculty of Letters, Department of Eastern Languages, Subdepartment of Russian Language and Literature.

${ }^{1}$ The official name "Yüzüncü Y1l Üniversitesi" which was stated in the title of Article 33 and the first sub-article of the Law No. 2809 is changed to "Van Yüzüncü Yıl Üniversitesi" in accordance with the Article No. 24 of the "Law of Making Amendments on Some Laws and Statuory Decrees related to Developing the Industry and Supporting the Manufacture which was enacted on 18.06.2017 with No.7033" which was published in the official gazette No. 30111 issued on July the 1 st, 2017.

Cite as/ Atıf: Eltut Kalender, N. (2020). Ana dili Kürtçe olan öğrencilerin Rusçayı ikinci yabancı dil olarak öğrenmeleri üzerine yapılan anket sonuçlarının analizi: Van Yüzüncü Y1l Üniversitesi Van MYO Turizm ve Otel İşletmeciliği ile turizm rehberliği programları örneği. Turkish Studies - Language, 15(2), 675-694. https://dx.doi.org/10.29228/TurkishStudies.42081

Received/Geliş: 09 March/Mart 2020

Accepted/Kabul: 20 June/Haziran 2020

Copyright $\odot$ INTAC LTD, Turkey

Checked by plagiarism software Published/Yayın: 27 June/Haziran 2020 CC BY-NC 4.0
} 
During the elementary school years, if students prefer to study at Foreign Language department field then second foreign language education becomes compulsory. On the other hand, general alternative foreign language options are mostly limited with German and French in elementary schools except the vocational training schools. At vocational training elementary schools where educational activities are organized on the grounds of pilot region or pilot school implementations, we see German and French are substituted with primarily Russian and Chinese as well as Italian and Spanish. At higher education institutions, students are offered opportunities to study different foreign languages according to their vocational training field requirements or individual interests. Students studying at the department of philology can take more than one foreign language as an elective depending on the departments' Resolutions of Academic Assembly.

This is an important study because it researches the fact that students who are enrolled at Van Yüzüncü Y1l University, Van Vocational School of Tourism-Hotel Management and Tourism Guidance programmes take Russian lesson as a vocational second foreign language. In this context, as a requirement of their future professional life, the students are recommended various foreign languages. They are offered: Persian due to being geographically close to Iran; Arabic due to hosting foreign students and visitors from Syria; and finally, German and Russian either because of the high demand for these languages in tourism and the employment opportunities out of Van. It is observed that students generally choose Persian and Russian lessons.

The purpose of this study is to research the difficulties and easiness that the students who grew up in a Kurdish spoken environment or who are enrolled in the aforementioned programmes and speak Kurdish as a mother tongue encounter during the Russian education offered as an elective lesson in second foreign language education. As the method of the study, the students are applied a questionnaire which consists of 22 questions to gather genuine and quantitative data. The population of the study is limited to 26 students who study at Van Yüzüncü Y1l University, Van Vocational School of Tourism-Hotel Management and Tourism Guidance programmes Russian class in 2015-2016 academic year.

The questionnaire doesn't collect the credentials of the students. However, the first two of the 22 questions require the participants to indicate the age range and gender. The questionnaire includes open-ended multiple-choice questions but no rating scale questions in the form of "I agree" or "I don't agree" to collect personal opinions.

The study searched answers of the following questions:

1. Depending on their mother tongue, is there a difference in students' capacity to learn Russian as the second foreign language?

2. Do the native-speaker students of Kurdish learn Russian as the second foreign language more easily than the other students?

3. Did the native-speaker students of Kurdish adopt the target language as a professional communication language which is the second foreign language for them?

4. Do the native-speaker students of Kurdish have a higher motivation to learn Russian compared to other students?

5. Are the students happy for having chosen Russian as the second foreign language?

Research findings are analyzed on SPSS v. 22.0 (The Statistical Packet of Social Sciences). Descriptive statistical methods are used in the analysis; students' answers to the questions are given in frequency and percentage tables and evaluated; independent sample t-test frequencies and percentages are calculated.

\section{Findings, Conclusion and Recommendations}

This study intends to research the students', especially the native-speaker students of Kurdish, motivations to learn Russian as a second foreign language at Van Yüzüncü Yıl University, Van Vocational School Tourism-Hotel Management and Tourism Guidance. Totally 26 students were applied a questionnaire which had 22 questions. In the questionnaire, the first three questions intended to reveal the personal characteristics of the participants; the second part aimed to determine which proficiencies the native-speaker students of Kurdish have related to their native language; the third part intended to determine which competencies the students attained as a result of learning Russian as a second foreign language, finally the fourth and last part included questions about environmental factors related to second foreign language.

When the answers of the five questions are reviewed in the framework of questionnaire analysis; 
It is seen that mother tongue differences affect the students' performance to learn Russian as a second foreign language. The students whose mother tongue is Turkish are guided by English as a bridge language in terms of vocabulary and grammatical structures, while the native-speaker students of Kurdish use methods of translation and comparison between Russian and their mother tongue Kurdish in terms of phonetics, stress, intonation and sentence structure. The native-speaker students of Kurdish are concluded to have a higher motivation to learn Russian as a second foreign language than the other students. Additionally, many of the students are found to be hesitating to make pronunciation and intonation mistakes during job shadowing and seasonal employments, though most of them think Russian as a second foreign language has great contributions to their professional capabilities. In other words, 50 percent of the students like having a conversation during the classroom hours but due to the lack of enough practice they feel uneasy and are afraid to communicate with the foreign tourists in Russian. Students' having the same academic calendar as the other faculties and high schools is another technical problem. This situation shows that the students are already late to go from eastern to the western or southern parts of Turkey, thus it is not possible for them to choose among the work places for job shadowing according to their competences and foreign language preferences; and also the work places offer them job shadowing in support services as they already found employees before that time, therefore they are deprived of possibilities to use their first and second foreign languages they learned. For this reason, increasing the weekly classroom hours of second foreign language to at least 4 hours, 2 hours theoretical and 2 hours practice, will certainly increase the success of the students.

The analysis of the data show that students are happy to have chosen Russian as the second foreign language.

The use of mother tongue has always been overlooked in literature even though it has been controversial in foreign language teaching techniques. What is meant here is not doing the lessons in the native language, it implies the necessity to develop new ways and methods in that foreign language by making comparisons with the native language. In this context, we can say that the teacher or the instructor must develop new methods according to the teaching environment, the capacity of the students, their interests, expectations and learning difficulties or fast learning. Existing studies will help developing foreign language techniques and reaching the expected levels of success. Consequently, mother tongue is the language that supports students; first foreign language functions as a bridge between the mother tongue and the target language; each language learned previously will be both a bridge and a supporting resource for all languages that will be learned later.

Keywords: Mother language (official language), mother tongue (native language) (L1), Kurdish, L3, Russian.

Öz: Doğu Anadolu Bölgesi'nde bulunan diğer illerde olduğu gibi, Van ilinde de birçok kişi tarafindan Kürtçe bilinmekte ve konuşulmaktadır. Kürtçe kendi içerisinde Kurmancî, Soranî, Lorî, Goranî, Zazakî (Kırdkî) olmak üzere lehçelere ayrılmaktadır. Van ilinde ise ana dili Kürtçe olan bireyler Kurmancî lehçesi ile konuşmaktadırlar. Dolayısıyla Van Yüzüncü Yıl Üniversitesi'nde ${ }^{2}$ de oldukça önemli sayıda ana dili Kürtçe olan öğrenci mevcuttur. 2013-2014 Eğitim-Öğretim Yılı Güz Yarıyılı’ndan itibaren Van Meslek Yüksek Okulu bünyesinde Turizm ve Otel İşletmeciliği ile Turizm Rehberliği Programlarında Rusça dersleri seçmeli statüde ikinci yabancı dil olarak okutulmaya başlanmıştır. İlgili programlarda kayıtlı ana dili Kürtçe olan öğrencilerin Rusça ile ana dilleri arasında telaffuz, vurgu, tonlama, kelime ve cümle yapısı bakımından benzerlik kurması neticesinde ana dili Kürtçe olmayan diğer öğrencilerden farklı öğrenme yöntemi geliştirdikleri saptanmıştır. $\mathrm{Bu}$ durum bir anket çalışması yapılmasını ve konunun araştırılmasını gerekli kılmıştır. Bu çalışma 2015-2016 Eğitim-Öğretim Yılı'nda ilgili programlara kayıtlı öğrencilere uygulanan anket çalışmasından elde edilen verilerin SPSS programı yardımıyla analizlerinin yapılarak değerlendirilmesi sonucunda ortaya çıkmıştır.

Anahtar Kelimeler: Ana dil (resmi dil), ana dili, Kürtçe, ikinci yabancı dil, Rusça.

${ }^{2} 1$ Temmuz 2017 tarih ve 30111 sayılı Resmi Gazete'de yayımlanan, “18.06.2017 tarih ve 7033 sayılı Sanayinin Geliştirilmesi ve Üretimin Desteklenmesi Amacıyla Bazı Kanun ve Kanun Hükmünde Kararnamelerde Değişiklik Yapılmasına Dair Kanun"un 24. maddesi gereğince, 2809 sayılı Kanunun 33. maddesinin başlığında ve birinci fikrasında yer alan "Yüzüncü Y1l Üniversitesi” ibareleri Van Yüzüncü Y11 Üniversitesi olarak değiştirilmiştir. 


\section{Giriş}

Bu çalışma Van Yüzüncü Yıl Üniversitesi, Van Meslek Yüksek Okulu'nun Turizm alanında Turizm ve Otel İşletmeciliği ile Turizm Rehberliği olmak üzere iki farklı programında kayıtlı öğrencilerin mesleki ikinci yabancı dil olarak Rusça dersini alması bakımından önem taşımaktadır. Söz konusu programlarda kayıtlı öğrencilerin bir kısmının ana dili Kürtçedir. Bu nedenle öncelikle ana dil, ana dili, birinci yabancı dil ve ikinci yabancı dil ile ilgili genel bilgiler verilmesi yerinde olacaktır.

\section{Ana Dil, Ana Dili, Birinci Yabancı Dil ve Íkinci Yabancı Dil}

Küzeci $(2015: 15,16)$ açıklayıcı bir yaklaşımla ana dil kavramını şu sözlerle tanımlar:

“Ana dil tek dildir. Kısa ve öz olarak herhangi bir eğitim program ve sürecine ihtiyaç duyulmadan veya katılmadan günlük ihtiyaç ve iletişimimizi sağladığımız kendiliğinden, aile fertleri arasında öğrendiğimiz ilk ve tek dildir. Ana dilimizle evreni tanır etrafımızdaki eşya ve fertlerin kim olduklarını ve neye yaradıklarını öğrenir, ihtiyaçlarımızı gideririz. Ana dil, içinde sürekli yaşadığımız bize ait toplumun dilidir ve bu dili paylaşır, onunla iletişimimizi kurarız. Ana dili çocuğun yaşayacağı toplumun eğitim düzeyine göre ve çocuğun öğrenme ortamındaki şartlara bağl1 olarak beş ila on beş yaşına kadar devam edebilir.”

"Ana dili" konusunda bir bireyin içerisine doğduğu ortama bağlı olarak ebeveynlerinin her ikisinin birden ya da ana dili farklı olan ebeveynlerden birisinin -genellikle annenin- baskın olarak çocukla iletişim kurduğu dildir diyebiliriz. Bu durumda birey ifade ve iletişim aracı olarak kullanabildiği ve düşünebildiği dilin taşıyıcısı rolünü üstlenir. Ancak "ana dil" ve "ana dili" kavramlarını birbirinden ayırmak gerekir. Türk Dil Kurumu'nun "Kendisinden başka diller veya lehçeler türemiş olan dil (https://sozluk.gov.tr) şeklinde tanımladığ "ana dil" kavramı görüldüğü üzere çoğunlukla uyruk bakımından ait olunan toplumun resmi dili olarak açıklanmaktadır ve bitişik değil, iki ayrı kelime olarak yazılmaktadır. Yine Türk Dil Kurumu "ana dili" kavramını "Çocuğun ailesinden ve içinde yaşadiğı topluluktan edindiği dil" (https://sozluk.gov.tr) olarak tanımlamaktadır ve söz konusu kavram iki ayrı kelime olarak yazılmaktadır. ${ }^{3}$ Bu nedenle ana dil ve ana dili kavramlarının birbirinden farklı iki kavram olduğunun altını çizmemiz gerekir.

Oruç (2016:318) ise; Küzeci'nin $(2015: 15,16)$ yukarıdaki ifadelerini destekler, fakat ana dilin tanımını yapmak yerine Türk Dil Kurumu'nun tanımı çerçevesinde "ana dil" kavramı üzerinden farklı bir açıklama yapmayı tercih etmiştir:

“Ana dili” kavramının tanımı her ne kadar "kişinin annesinden, doğup büyüdüğü çevrede öğrendiği dil” ise de gelişen ve küreselleşen dünyada uzaklıkların yakın olduğu, göçlerin yoğunlaştığı, ülkeler arası sınırların özellikle Avrupa Birliği üyesi ülkelerin sınırlarının neredeyse kalktığı günümüz dünyasında "ana dili” kavramını "anne dili" kavramı tam olarak karşılamamaktadır. Çünkü "ana dili” kavramını bazı dilciler "kişinin kendisini en rahat, en iyi ifade ettiği dil” olarak da tanımlamaktadırlar.

"Birinci yabancı dil nedir?" dersek akla ilk önce eğitimin bir parçası olan zorunlu yabancı dil dersleri gelebilir. Oysaki birinci yabancı dil için şöyle daha geniş bir tanımlama yapabiliriz: bir bireyin kişisel, ailesel, çevresel istek doğrultusunda, eğitim ya da kariyer odaklı çeşitli etkenler sonucunda içerisinde bulunduğu koşullar gereği ana dili dışında öğrenme çabasına girdiği bir başka dildir.

\footnotetext{
${ }^{3}$ Yazım konusunda önceleri birleşik kelime olarak karşımıza çıkan "ana dil” ve "ana dili” kavramlarının ayrı kelimeler olarak yazılmasına birçok kişi halen alışamamıştır. Yayımlanan akademik çalışmaların bazılarında "anadil" ya da "anadili" şeklinde birleşik kelime olarak yazımı karşımıza çıkmakta, bazılarında ise günümüz Türk Dil Kurumu kullanımına göre yazımını görmekteyiz. Söz konusu çalışmamızda Türk Dil Kurumu'nun güncel kullanımı esas alınmıştır.
} 
Türkiye'de yabancı dil öğrenimi ilkokul ikinci sınıftan itibaren uluslararası en yaygın kullanıma sahip olması bakımından eğitim kurumlarının tamamında okutulması kararlaştııılan ortak birinci yabancı dil olarak İngilizce ile başlamaktadır. Aydın (2006:273) ülkemizde de İngilizcenin yabancı bir dil olarak yoğun bir biçimde öğretilmesini içerisinde bulunduğumuz çağda, İngilizcenin ekonomik, sosyal, politik, sanatsal ve bilimsel alanlarda küresel olarak ortak bir dil olmasina bağlamaktadır. İlkokul yıllarında başlayan yabancı dil öğrenim süreci öğrenim hayatı boyunca devam etmektedir. İlk etapta İngilizce ile başlayan yabancı dil öğrenimi zorunlu eğitimin bir parçasıdır. Ancak kimi eğitim kurumlarında zorunlu yabancı dil İngilizce dersine ilave kişisel tercihe bırakılmış seçmeli statüde ikinci yabancı dil alternatifleri de bulunmaktadır. İlkokuldan öğrenim hayatının sona ereceği üniversite öğreniminin sonuna kadar uzanan yabancı dil öğrenimi konusunda herhangi bir sinırlılık bulunmamaktadır.

Akalın ve Zengin $(2007: 181,182)$ yabancı dil öğrenmenin ve kullanmanın önemini Demirel (2003:17)'den yaptığı alıntı ile Avrupa Konseyi örneğini ve Huljstin (2006)'den yaptığı alıntıyla Avrupa'nın yabancı dil edinimi politikasını şu ifadelerle aktarmaktadır:

“Türkiye'nin 1950 yılında ilk katılan ülkelerden biri olduğu ve tüm çalışmalarına kesintisiz katıldığı Avrupa Konseyi’nin amaçlarından biri farklı kültürlere sahip Avrupa vatandaşları arasında karşılıklı anlayışı geliştirmek ve tüm bireylere Avrupa kimliğini kazandırmaktır. Resmi dili İngilizce ve Fransızca olan Konsey, bu amaçta başarılı olmak için 2001 yılını 'Avrupa Diller Yılı' olarak ilan ederek Avrupa'da konuşulan çeşitli dillerden en az ikisi ya da üçünü kullanmanın ekonomik, sosyal ve kültürel yaşam için ne kadar değerli olduğunun altını çizmiştir (Demirel, 2003:17). Hulstijn (2006), Avrupa Birliği'nin her Avrupa vatandaşı için benimsediği resmi standardın yeterli düzeyde en az iki dili bilmek olduğunu belirtir. Dil ediniminin gelişmesi için yapılan araştırmaların çoğunlukla ulusal ve kurumsal sınırlar içinde kalmasını eleştirerek, ulusal ve uluslararası veri ağları kurulması gereğinin altını çizer."

Koçak ve Çobanoğulları (2017:1) her geçen gün insanlar arasındaki iletişim ihtiyacının daha da artmasına, iş başvuruları vb. durumlarda İngilizcenin yanı sıra ikinci bir dil bilgisinin de istenmesine ve bazı iletişimsel durumlarda İngilizcenin yetersiz kalmasına bağlı olarak ikinci bir yabancı dilin öğrenilmesinin gerekli hale geldiğini savunmaktadır.

Giriş bölümünde de belirtildiği üzere ikinci yabancı dil öğretimi Türkiye'de orta öğretim sürecinde kendisini göstermektedir. Yani ikinci yabancı dil, dilbiliminde ana dil edinimini takiben, "ikinci dil edinimi" olarak adlandırılan birinci yabancı dil öğreniminin ardından öğrenilmeye başlanır. Akpınar Dellal ve Günak (2009: 22) öğrencilerin ikinci yabancı dile, birinci yabancı dilini öğrenirken geliştirdiği öğrenme alışkanlıkları ve stratejilerle donanımlı olarak başladığı ve ikinci yabancı dili öğrenirken genellikle birinci yabancı dilinden yardımlar aldığı görüşünü savunmaktadır.

Türkiye'de ortaöğretim yıllarında alan tercihi olarak Yabancı Dil alanı seçilmesi halinde ise ikinci yabancı dil öğrenimi zorunlu olarak öğrencilerin karşısına çıkmaktadır. Ancak bu noktada mesleki orta öğretim kurumları dışında genel itibariyle sunulan alternatif yabancı dil yelpazesi çoğunlukla Almanca veya Fransızca ile sınırlandırılmaktadır. Akpınar Dellal ve Günak (2009: 22) Türkiye'de 1980'li yılların ortalarına kadar okullarda öğrencilere genellikle İngilizce, Almanca veya Fransızca dillerinden biri öğretilmekteyken, 1980'li yılların sonunda alınan siyasi kararlarla, Almanca ve Fransizcanın okulların genelinden kaldırıldığını ve tek yabancı dil uygulaması başladığını söyler. Ancak 1997 yılında kabul edilen "Sekiz Yıllık Zorunlu ve Kesintisiz Eğitim Yasası" ve Avrupa Birliği Yabancı Dil Politikası çerçevesinde 2001 yılı etkinlikleri neticesinde Almanca ve Fransızca ikinci yabancı dil olarak ülkede yeniden önemsenmeye başlanmıştır (Akpınar Dellal ve Günak, 2009:22).

Can ve Can (2014:44) alanda yapılan araştırma ve gözlemlere dayanarak, ikinci yabancı dil öğretimi ve öğrenimi kapsamında genellikle Almanca ve Fransızca dillerinin esas alındığını ifade eder, ancak bu dillerin öğretimi ve öğrenimine birinci yabancı dil olarak ön plana çıkan İngilizce 
kadar önem verilmediği, önemsenmediği görüşünü savunmaktadır. Can veCan bu görüşü güçlendirmek adına Avrupa Eğitim Bilgi Ağı resmi verileri bağlamında bir örnek vermektedir:

\begin{abstract}
"Örneğin, Avrupa'da okullarda dil öğretimi hakkındaki temel veriler incelendiğinde (EURYDICE, 2008:7,8), İngilizce, Fransizca, Almanca, İspanyolca, Rusça, öğrenilen bütün dillerin \%95'ini temsil etmekte, İngilizce öğretimi sürekli olarak genişlemekte ve hemen hemen her yerde hâkim olmaktadır. Ortaöğretim ikinci kademedeki öğrencilerin \% 90 civarı, zorunlu olsun ya da olmasın öncelikle İngilizceyi öğrenmektedir. Ayrıca, Almanca veya Fransızca en yaygın olarak öğrenilen ikinci yabancı dil olarak ortaya çıkmaktadır." (Can ve Can, 2014:44)
\end{abstract}

Mesleki orta öğretim kurumlarında ise pilot bölge ya da pilot okul uygulaması esasına dayanan eğitim-öğretim kurumlarında başta Rusça ve Çince olmak üzere İtalyanca, İspanyolca gibi dillerin klasik yabancı dil alternatiflerinden Almanca ve Fransızcanın yerini aldığını görmekteyiz. Yüksek öğrenim sürecine gelindiğinde ise filoloji alanları dışında herhangi bir alana kayıtlı öğrencilerin ilk ve orta öğrenim geçmişinde almış oldukları yabancı dil gözetilerek birinci sınıf zorunlu dersleri arasında söz konusu yabancı dil dersini başarı ile tamamlaması beklenmektedir. Yükseköğretim kurumlarında öğrencilerin mesleki alan çalışmalarını ilgilendirmesi ve kişinin ilgi alanlarına istinaden tercih edebilmesi amacıyla seçmeli statüde antik, doğu, batı, Slav ve Kafkas dilleri grubuna giren çeşitli yabancı dilleri öğrenmesine imkân tanınmaktadır. Filoloji alanlarında öğrenim gören öğrencilerin ise ilgili bölümün Akademik Kurul Kararı'na bağlı olarak seçmeli statüde birden fazla yabancı dil öğrenme olanağı bulunmaktadır.

İkinci yabancı dilin okullarda öğretilmesi, sadece iş hayatında ve iletişim alanlarında sağlayacağı avantajlardan ötürü değil, Avrupa Birliği'ne dâhil olma hedefi olan Türkiye'nin Avrupa Birliği ile uyum içerisinde olabilmesi için de gereklidir (Koçak ve Çobanoğulları: 2017:1).

Avrupa Konseyi'nin 2001 yılında yürürlüğe koyduğu “Avrupa Ortak Dil Kriterleri Çerçeve Programı"nda vurgulanan "çok dillilik" ve "Avrupa Dil Portfolyosu" kavramları da Türkiye'deki ikinci, hatta üçüncü yabancı dil eğitimine bakış açısını olumlu yönde değiştirmiş, bu doğrultuda eğitim çalışmalarının yürütülmesini sağlamıştır (Balcı, 2016:347).

Van Yüzüncü Yıl Üniversitesi, Van MYO, Turizm ve Otel İşletmeciliği ve Turizm Rehberliği Programları'nda da mesleki yeterlik göz önünde bulundurularak yabancı dil yelpazesi geniş tutulmaktadır. Bilindiği üzere Doğu Anadolu Bölgesi'ndeki birçok ilde olduğu gibi, Van'da yaşayan halkın çoğunluğunun da ana dili Kürtçedir. Oruç $(2016: 317,318)$ ana dil ve ana dili arasındaki farklılığ açıkladığ çalışmasında bu konuya temas etmektedir ve Türkiye de birçok etnik grup olduğunu ve her birinin ait olduğu etnik gruba göre farklı ana diline (anne diline) sahip olduğunu, bu durumda etnik köken bakımından Kürt olanların ana dilinin de Kürtçe olduğunu söylemekte, fakat Türkiye Cumhuriyeti'nde resmi dili olarak ana dilin Türkçe olduğunun altını çizmektedir. Dolayısıyla burada bahsi geçen etnik kökene ait ana dili ve ülkenin resmi diline hâkim bireyler için dilbiliminde "bilingual" yani "ikidilli" terimi kullanılmaktadır.

Van Yüzüncü Yıl Üniversitesi, Van MYO, Turizm ve Otel İşletmeciliği ve Turizm Rehberliği Programları'nda öğrenim gören öğrencilerin büyük bir kısmı bilingual bireylerden oluşmaktadır. Söz konusu programlarda eğitim dili bilindiği üzere Türkçe, birinci yabancı dilleri ise İngilizcedir. Ancak meslekleri gereği öğrencilere başta coğrafi olarak İran'a yakınlığ 1 ve Van'a çok sayıda İranlı turist gelmesi nedenleri ile Farsça; Irak ve Suriye'den yabancı konuk gelmesi nedeniyle Arapça ve Van dışında sahip olacakları iş olanakları gözetilerek turizm sektöründe en çok ihtiyaç hissedilen Almanca ve Rusça dersleri önerilmektedir. Genel olarak öğrencilerin Farsça ve Rusça derslerine rağbet ettikleri görülmektedir. Ancak uygulanan eğitim-öğretim programı gereği öğrencilerin alabilecekleri ders kredileri kısıtlı olduğu için seçmeli statüdeki ikinci yabancı dil derslerine haftada iki saat ayrılmıştır. Öğrencilere birinci sınıfta ve mezun olacakları ikinci sınıfta toplam dört dönem ikişer saatlik ikinci yabancı dil dersleri verilmektedir. 
İkinci yabancı dil olarak Rusça seçen öğrenciler arasında etnik köken bakımından farklılıklar olmasının ikinci yabancı dil öğrenme motivasyonlarına etki ettiği görülmüştür. Sınıf içinde yapılan yazılı ve sözlü performans etkinlikleri neticesinde ana dili Türkçe olan öğrencilerin Rusça öğreniminde kelime ve gramer yapıları bakımından köprü dil İngilizceden güdülenirken, ana dili Kürtçe olan öğrencilerin ses yapısı, vurgu, tonlama ve cümle yapısı bakımından öğrenmekte oldukları ikinci yabancı dil Rusça ve ana dilleri olan Kürtçe arasında karşılaştırma yöntemine başvurduğu tespit edilmiştir.

Arak (2006:215) karşılaştırmalı dilbilgisi incelemelerinin yabancı dil dersinde kullanılabilmesi için iki dilin tüm yönleriyle karşılaştırılmasının bir zorunluluk olduğunu, böylelikle de ortaya konan dilbilgisi incelemeleri yardımıyla kullanılan ana dil sistemi üzerine yabancı dil inşa edilebileceğini ifade etmektedir ve sözlerini şu şekilde sürdürmektedir:

\footnotetext{
“...Böylece ana dil olumlu aktarmalar yardımıyla yabancı dil öğrenimine olumlu katkıda bulunabilir. Yabancı dil ile ana dil arasında farklı derecede önem taşıyan farklılıklar ve benzerlikleri tam olarak açığa çıkarabilmek için her iki dilin tüm yapılarının en ince ayrıntısına kadar karşılaştırmalı olarak incelenmiş ve tanımlanmış olması gerekir. Dillerin sadece belirli yapılarının karşılaştırılması karşılaştırmalı çalışmalar için yeterli değildir. Özellikle ana dildeki bir yapının yabancı dilde hiç olmaması halinde ne gibi öğrenme güçlüklerinin ortaya çıktığı böylece belirlenebilir."
}

Demirel (2012:144)'den edindiğimiz bilgiye göre, yabanc1 dil ediniminde öğrenme stratejileri konusunda Oxford (1993), strateji kullanımını etkileyen faktörlerin konu olduğu araştırmaları incelemiş ve bu kapsamda cinsiyet, etnik ve kültürel kökenlerin, motivasyon düzeyinin, yaşın, dil yeterlik düzeyinin, öğrenme görevinin ve öğrenme stillerinin strateji kullanımında belirleyici olduğunu ortaya koymuştur. Öğrencilerin dil öğrenme stratejilerinden ne ölçüde yararlandıklarının belirlenmesi ve bu doğrultuda eksiklerin giderilmesi dil öğretiminde etkililiği arttırabilecek önemli bir girişimdir. Demirel (2012:144) Türkiye'de bu tür çalışmaların örgün eğitimin rutin etkinlikleri arasında yer almadığına vurgu yapmaktadır.

Memiş (2018:1286)'in konuya ilişkin görüşü ise; öğrencilerin kelimenin anlamını tüm çabalara rağmen tam olarak kavrayamaması halinde öğreticinin kullanacağı dile hâkim olması kaydıyla kelimenin, öğrenenlerin ana dilindeki veya araç dil olarak kullandıkları dildeki karşılığının doğrudan söylenmesinin öğrencilerin öğrenme motivasyonlarını artıracağ 1 yönündedir. Ayrıca yine Memiş (2018:1286)'e göre kelime öğrenim şekilleri yaşa bağlı olarak farklılık göstermektedir. Çocuklar ve yetişkinler birbirinden farklı şekillerde kelime öğrenmeye meyillidir. Çocuklar kelimeleri oyunlar aracılığıyla daha kolay öğrenirken yetişkinler ise kelimelerin daha çok ana dilindeki karşılığını bularak çeviri yoluyla öğrenmeyi tercih etmektedir.

Yapmış olduğumuz araştırmaya konu olan öğrenci grubunun da tam olarak bilinçli olmasa da ikinci yabancı dil olarak Rusçayı öğrenirken Memiş (2018:1286)'in sözünü ettiği kelimelerin daha çok ana dilindeki karşılığını bularak çeviri yoluyla öğrenme yöntemine başvurdukları gözlenmiştir.

Şevik (2007:102) ise yabancı dil sınıflarında öğrencilerin ana dillerinin kullanımına ilişkin çeşitli görüşler bulunduğunu bildirmektedir. Bu görüşler doğrultusunda birçok araştırmacıya göre yabancı dil öğretim metotları bakımından sınıf içerisinde sadece hedef dilin kullanılması gerekmekteyken, bir grup araştırmacıya göre sınıf içinde ana dilin kullanılması yabancı dil öğretimine katkıda bulunabilmektedir. Şevik (2007:102) bu çalışmasında özellikle son yıllarda, konu hakkında yapılan araştırmaların bilinçli ve limitli ana dil kullanımının yabancı dil öğretiminde gerekli ve kolaylaştırıcı bir rolü olduğu görüşünü ortaya koyduğunun altını çizmektedir.

Şevik (2007:113) iki dilli öğretim metodunun üç ayrı avantajı olduğunu şu sözlerle dile getirmektedir: 
"Bunlardan ilki, yabancı dildeki kelimelerin anlamlarının anında görülerek anlam tahmini ile vakit harcanmamasıdır. Ana dilin kullanılması sonucu, anlam yabancı dil öğreniminin ilk aşamalarında hemen anlaşılır ve bu durum öğrenmenin gerçekleşmesini garanti altına alır. İkincisi, iki dilli yöntem öğrencilerin ana dillerini de geliştirmelerine olanak tanır ve iki dilin sürekli karşılaştırılması sonucu yabancı dildeki yeni kelimeler ve temel yapılar içselleştirilmiş olur ve iki dil arasında kavramsal bir bağ kurulmasına yardımcı olur. Üçüncü olarak ise ana dil kullanımı yabancı dil öğreniminin ilk aşamalarında doğal bir eğilim olan anlam edinimi gereksinimini kolaylaştırır. Küçük yaşlardaki öğrenciler henüz olgun olmadıkları için tek dilli yöntemin uygulamalarını ve bu yönde hazırlanan kitapları cazip bulmayıp, anlayamadıkları bu yeni dilden uzaklaşabilirler. Sonuç olarak, ana dilin yabancı dil sınıflarında kullanılması özellikle erken yaşlardaki yabancı dil öğrencilerinin öz güvenlerinin ve motivasyonlarının artırılmasında önemli bir rol oynayabilir."

Ayrıca Neuner ve Hufeisen (2001:160 (akt.Hanbay, 2013:273))'e göre ikinci yabancı dil dersinde birinci yabancı dil ve ana dilinden kaynaklı dilsel bilgilerin kullanımından oluşan dekleratif bilgi ve birinci yabanc1 dili öğrenirken edinilen öğrenme yöntem ve teknik bilgiden oluşan prosedürel bilgiden özellikle yararlanmak gerekmektedir.

\section{Ampirik-Nicel Araştırma}

\section{Araştırmanın Amacı, Yöntemi, Evreni ve Sınırlııkları}

Herhangi bir siyasi amaç güdülmeksizin, alana ilişkin karşılaştırmalı dilbilim ve filoloji çalışmalarına temel oluşturmak ve/veya katkı sağlamak niyetiyle hazırlanan söz konusu çalışmanın amacı, Van Yüzüncü Yıl Üniversitesi'nde öğrenim gören ana dili Kürtçe olan ya da Kürtçe konuşulan ortamda yetişmiş öğrencilerin ikinci yabancı dil olarak zorunlu seçmeli statüde verilen Rusça öğreniminde yaşadıkları kolaylık ve zorlukları tespit etmektir. Bu çalışmada gerçekçi ve nicel veriler elde etmek amacıyla öğrencilere 22 sorudan oluşan bir anket çalışması uygulanmıştır. Araştırmanın evrenini 2015-2016 Eğitim-Öğretim Yılı'nda Van Yüzüncü Yı1 Üniversitesi, Van Meslek Yüksek Okulu'nun Turizm ve Otel İşletmeciliği Programı ile Turizm Rehberliği Programı'nda öğrenim görmekte olan 26 öğrenci oluşturmuştur. Veri toplama sürecinde, Dr. Öğr. Üyesi Nükhet Eltut Kalender (2015-2016 Eğitim - Öğretim Y111) tarafından geliştirilen "İkinci yabancı dil Rusça dersinde ana dilinin öğrenme motivasyonuna etkisini belirleme ölçeği” kullanılmıştır.

Ankette öğrencilerin isim ve soyisim bilgileri sorulmamıştır. Ancak ankete verilen cevapların yaş ve cinsiyet dağılımına göre analizinin yapılması bakımından 22 sorunun ilk ikisi yaş aralığı ile cinsiyetin belirtilmesine yönelik sorulardan oluşmuştur. Öğrencilere yöneltilen diğer sorularla Kürtçe ve Rusça kelime bilgisi, okuma, yazma ve konuşma gibi dil becerilerinin tespit edilmesinin yanı sıra ana dili Kürtçenin mesleki ikinci yabancı dil olarak Rusça öğreniminde ne denli etkiye sahip olduğunun ortaya çıkarılması hedeflenmiştir. Ankette öğrencilere yöneltilen sorular açık uçlu çoktan seçmeli sorulardan oluşmakta olup, "katılıyorum, katılmıyorum" gibi kişisel düşünce belirtilmesine yönelik derecelendirme sorularına yer verilmemiştir. Çalışma evreni Van Yüzüncü Yıl Üniversitesi, Van MYO, Turizm ve Otel İşletmeciliği ile Turizm Rehberliği Programlarında Rusça dersine kayıtlı öğrenciler ile sınırlı olup, yapılacak analiz neticesinde Üniversite genelini ya da Doğu Anadolu Bölgesi'ndeki diğer üniversiteleri etkileyecek genelleyici bir sonuca ulaşılması beklenemez.

Araştırma esnasında aşağıdaki sorulara yanıt aranmıştır:

1. Öğrencilerin ana dili farklılıklarına göre ikinci yabancı dil Rusçayı öğrenme performansları arasında fark var midır?

2. Ana dili Kürtçe olan öğrencilerin ikinci yabancı dil olarak Rusçayı öğrenmesi diğer öğrencilerden daha mı kolaydır?

Turkish Studies - Language, 15(2) 
3. Ana dili Kürtçe olan öğrenciler ikinci yabancı dil konumundaki hedef dili mesleki iletişim dili olarak benimsemişler midir?

4. Ana dili Kürtçe olan öğrencilerin Rusçayı öğrenme motivasyonları diğer öğrencilerden daha mı yüksektir?

5. Öğrenciler seçmeli ikinci yabancı dil olarak Rusçayı tercih etikleri için memnun mudur?

Araştırma sonucunda elde edilen bulgularının analizi SPSS (The Statistical Packet of Social Sciences) Programı'nın 22.0 sürümü yardımı ile yapılmıştır. Analizde betimleyici istatistik yöntemlerden yararlanılmış, sorulara verilen yanıtlar frekans ve yüzdesel olarak tablolaştırılmış, değerlendirme yapılmış, bağımsız örneklem t-testi sıklık ve yüzdelikler hesaplanmıştır.

"Eğitim kalitesinin niteliksel ve niceliksel olarak ölçülmesi amacıyla bazı araştırmalara ve sayısal değerlere gereksinim duyulmaktadır. Anket ve araştırmaların belirli aralıklarla yapılması ve nesnel verilerin elde edilmesi önemlidir. İşlenen derslerin kalitesinin değerlendirilmesinde çoğu zaman öğrencilerin de söz sahibi olmaları istenmektedir. Bu bağlamda öğretim elemanı hakkında ve işlenen dersler konusunda öğrencilerin ne düşündüklerini bilmek, "kara kutunun" içine bir bakış atmak olacaktır" (Mesbah, 2013:294).

\section{Bulgular}

\begin{tabular}{|c|c|c|c|c|c|}
\hline & & Frequency & Percent & Valid Percent & $\begin{array}{c}\text { Cumulative } \\
\text { Percent }\end{array}$ \\
\hline \multirow[t]{5}{*}{ Valid } & $17-20$ & 5 & 19,2 & 19,2 & 19,2 \\
\hline & $20-23$ & 19 & 73,1 & 73,1 & 92,3 \\
\hline & $23-26$ & 1 & 3,8 & 3,8 & 96,2 \\
\hline & $26-30$ & 1 & 3,8 & 3,8 & 100,0 \\
\hline & Total & 26 & 100,0 & 100,0 & \\
\hline
\end{tabular}

Yukarıdaki tablo verilerinden uygulanan ankete katılan öğrencilerin \% 73,1'inin (19 öğrencinin) 20-23 yaş grubu aralığında olduğunu görülmüştür.

Tablo 2. Araştırma Grubu "Cinsiyet” Dağılımı

\begin{tabular}{|c|c|c|c|c|c|}
\hline & & Frequency & Percent & Valid Percent & $\begin{array}{c}\text { Cumulative } \\
\text { Percent }\end{array}$ \\
\hline \multirow[t]{3}{*}{ Valid } & Erkek & 10 & 38,5 & 38,5 & 38,5 \\
\hline & Kadın & 16 & 61,5 & 61,5 & 100,0 \\
\hline & Total & 26 & 100,0 & 100,0 & \\
\hline
\end{tabular}

Araştırmaya katılan 26 öğrencinin tamamı cinsiyetini belirtmiştir. 26 kişinin \% 38,5'inin (10’unun) erkek, \% 61,5'inin (16’sının) ise kadın öğrenci olduğu tespit edilmiştir. 
Tablo 3: "Kürtçe Ana Diliniz mi?” Sorusuna Göre Cevap Dağılımı

\begin{tabular}{|cc|c|c|c|c|}
\hline & & & & Cumulative \\
& & Frequency & Percent & Valid Percent & Percent \\
\hline \multirow{2}{*}{ Valid } & Evet & 17 & 65,4 & 65,4 & 65,4 \\
& Hayır & 9 & 34,6 & 34,6 & 100,0 \\
& Total & 26 & 100,0 & 100,0 & \\
\hline
\end{tabular}

Anket soruları içinde yaş aralığı ve cinsiyet sorusunu takip eden ikinci bölüme ait ilk soru "Kürtçe ana diliniz mi?" sorusu idi. Bu soruya öğrencilerin tamamı cevap vermiş olup, ikinci yabanc1 dil olarak Rusça dersini seçen öğrencilerin çoğunun, yani \% 65,4'lük bir grubun (17 öğrencinin) ana dilinin Kürtçe olduğu belirlenmiştir. Bu öğrenciler sınıfta bilingual ya da ikidilli olarak adlandırılan öğrenci grubunu oluşturmaktadır.

Tablo 4: “Çevrenizdeki Kişilerle Kürtçe İletişim Kurabiliyor musunuz?” Sorusuna Göre Cevap Dağılımı

\begin{tabular}{|c|c|c|c|c|c|}
\hline & & Frequency & Percent & Valid Percent & $\begin{array}{c}\text { Cumulative } \\
\text { Percent }\end{array}$ \\
\hline \multirow{5}{*}{ Valid } & Evet & 12 & 46,2 & 46,2 & 46,2 \\
\hline & $\begin{array}{l}\text { Anlayabiliyorum ama hiç } \\
\text { konuşamıyorum }\end{array}$ & 5 & 19,2 & 19,2 & 65,4 \\
\hline & Biraz & 4 & 15,4 & 15,4 & 80,8 \\
\hline & Hiç & 5 & 19,2 & 19,2 & 100,0 \\
\hline & Total & 26 & 100,0 & 100,0 & \\
\hline
\end{tabular}

Öğrencilerin kaçta kaçı Kürtçeyi ne kadar bilmektedir bunu net olarak bilmediğimiz için öğrencilere Kürtçe bilgi ve okuma, yazma, konuşma yetilerinin düzeyini öğrenmeyi amaçlayan birkaç soru yöneltilmiştir. $\mathrm{Bu}$ sorulardan ilki Kürtçeyi iletişim dili olarak kullanıp kullanamadıklarıdır. Yukarıdaki tablodan anlaşılacağı üzere anket çalışmasına katılan öğrencilerden \% 46,2'si çevresindeki kişilerle Kürtçe iletişim kurabilmekte, \% 19,2'si Kürtçe anlamasına karşın söz konusu dili iletişim dili olarak kullanamamakta, \% 15,4'ü çevresindekilerle biraz Kürtçe iletişim kurabilmekteyken, \% 19,2'si ise çevresindekilerle Kürtçe iletişim kuramamaktadır. Buradan anlaşılan \% 46,2'lik dilimi oluşturan öğrencilerin dışında kalan \% 15,4 ve "hiç" yanıtı veren \% 19,2'lik dilimi temsil eden öğrenciler Tablo 3 'te yer alan ana dili Kürtçe olmayan \% 34,6'llk grubu oluşturmaktadır. 
Tablo 5: "Çevrenizde Aileniz, Yakınlarınız ya da Arkadaşlarınız Arasında Kürtçe (Lehçeler Hariç) Konuşulduğunda Konuşmanın Ne Hakkında Olduğunu Ve/Veya Söylemlerini Anlayabiliyor

\begin{tabular}{|c|c|c|c|c|c|}
\hline & & Frequency & Percent & Valid Percent & $\begin{array}{l}\text { Cumulative } \\
\text { Percent }\end{array}$ \\
\hline \multirow[t]{6}{*}{ Valid } & Tamamen anliyorum & 10 & 38,5 & 38,5 & 38,5 \\
\hline & Kismen anliyorum & 10 & 38,5 & 38,5 & 76,9 \\
\hline & Çoğunluğunu anlıyorum & 2 & 7,7 & 7,7 & 84,6 \\
\hline & $\begin{array}{l}\text { Sadece birkaç kelime ya da } \\
\text { cümle anlayabiliyorum }\end{array}$ & 2 & 7,7 & 7,7 & 92,3 \\
\hline & Hiç anlayamıyorum & 2 & 7,7 & 7,7 & 100,0 \\
\hline & Total & 26 & 100,0 & 100,0 & \\
\hline
\end{tabular}

Tablo 5 araştırmaya dâhil olan öğrenci grubunun \% 38,5'inin yakın çevrelerinde Kürtçe konuşulduğunda tamamını anladığını, \% 7,7'sinin ise hiçbir şey anlayamadığını göstermektedir, geri kalan \% 53,9'luk dilimde \% 7,7'sinin sınırlı kelime ya da cümle anladığ düşünüldügünde ana dili Kürtçe olmayan öğrencilerin bulundukları okul ortamında ya da çevrelerindekileri kişilerden belli başlı kelime ve ifadeyi öğrenmiş olduğu sonucuna varılmaktadır.

Tablo 6: "Kürtçe Tabela ve Döviz Yazılarını, Medya Organları Tarafından Hazırlanmış Yazılı Yayınları (Kitap, Dergi, Makale, Köşe Yazısı, Tanıtım Broşürleri vs) ya da Gördüğünüz Kürtçe

Yazılmış Herhangi Bir Metni Okuyabiliyor musunuz?” Sorusuna Göre Cevap Dağılımı

\begin{tabular}{|c|c|c|c|c|c|}
\hline & & Frequency & Percent & Valid Percent & $\begin{array}{l}\text { Cumulative } \\
\text { Percent }\end{array}$ \\
\hline \multirow[t]{6}{*}{ Valid } & Evet & 6 & 23,1 & 23,1 & 23,1 \\
\hline & $\begin{array}{l}\text { Okuyorum ama tamamını } \\
\text { anlayamıyorum }\end{array}$ & 4 & 15,4 & 15,4 & 38,5 \\
\hline & $\begin{array}{l}\text { Konuşabiliyorum ama Kürtçe } \\
\text { yazıları okuyamıyorum }\end{array}$ & 4 & 15,4 & 15,4 & 53,8 \\
\hline & Kürt alfabesini bilmiyorum & 9 & 34,6 & 34,6 & 88,5 \\
\hline & $\begin{array}{l}\text { Harfleri biliyor ve yazıları } \\
\text { okuyorum ancak hiç } \\
\text { anlamıyorum }\end{array}$ & 3 & 11,5 & 11,5 & 100,0 \\
\hline & Total & 26 & 100,0 & 100,0 & \\
\hline
\end{tabular}

Tablo 6 araştırmaya katılan öğrencilerin \% 34,6'sının Kürt alfabesini bilmediğini ortaya koymuştur. Tablo 3'te ana dilinin Kürtçe olmadığını belirten öğrenci yüzdesi $(\% 34,6)$ ve tablo 4'de çevresindeki kişilerle Kürtçe iletişim kurma noktasında "biraz" (\% 15, 4) ya da "hiç" yanıtı veren (\% 19,2) öğrenci yüzdesinin toplamı (\% 34,6) ile örtüşmektedir.

Araştırmaya dâhil olan grup içerisinde Kürtçe tabela ve döviz yazılarını, medya organları tarafından hazırlanmış yazılı yayınları (kitap, dergi, makale, köşe yazısı, tanıtım broşürleri vs) ya da gördükleri Kürtçe yazılmış herhangi bir metni okuyup okuyamadıkları sorusuna verilen cevaptan \% 34,6'sının Kürt alfabesini bilmediği (ana dili Kürtçe olmayan grubu ifade etmektedir bkz. Tablo 3), ana dili Kürtçe olan öğrencilerden sadece \% 23,1'inin bu tür yazıları okuyabildiği öğrenilmiştir. Geri kalan öğrenciler ise kısmen söz konusu yazıları okuyabilmekte ya da okuduklarını anlayabildiklerini ifade etmişlerdir. 
Tablo 7: “Kürtçe Yazı Yazabiliyor musunuz?” Sorusuna Göre Cevap Dağılımı

\begin{tabular}{|c|c|c|c|c|c|}
\hline & & Frequency & Percent & Valid Percent & $\begin{array}{c}\text { Cumulative } \\
\text { Percent }\end{array}$ \\
\hline \multirow[t]{7}{*}{ Valid } & Evet & 4 & 15,4 & 15,4 & 15,4 \\
\hline & $\begin{array}{l}\text { Konuşabiliyorum ancak } \\
\text { yazamıyorum }\end{array}$ & 3 & 11,5 & 11,5 & 26,9 \\
\hline & $\begin{array}{l}\text { Hem konuşabiliyorum hem } \\
\text { de okuyabiliyorum ancak } \\
\text { yazamiyorum }\end{array}$ & 1 & 3,8 & 3,8 & 30,8 \\
\hline & $\begin{array}{l}\text { Okuyabiliyorum ancak } \\
\text { yazamıorum }\end{array}$ & 5 & 19,2 & 19,2 & 50,0 \\
\hline & Kürt alfabesini bilmiyorum & 9 & 34,6 & 34,6 & 84,6 \\
\hline & Bazen harfleri karıştırıyorum & 4 & 15,4 & 15,4 & 100,0 \\
\hline & Total & 26 & 100,0 & 100,0 & \\
\hline
\end{tabular}

Tablo 7'de Kürtçe yazı yazabilme yetileri konusunda kendilerine yöneltilen soruya sadece öğrencilerin \% 15,4'ünün olumlu yönde net cevap verdiği görülmüsşür. Ancak \% 34,6 oranında Kürt alfabesini bilmediği yanıtını veren öğrenci grubu tablo 3, tablo 4 ve tablo 6' da aynı yüzdelik dilimi $(\%$ 34,6) temsil eden öğrencilerden oluşmaktadır. Evren grubunun geri kalan \% 50'sinin ise Kürtçe yazma yetisine sahip olmadığı belirlenmiştir. Ancak ana dili Kürtçe olan öğrencilerden \% 19,2'sinin Kürtçe okuma yetisi olmasına karşın yazı yazma yetisine sahip olmadığı tespit edilmiştir.

Tablo 8: "Neden Mesleki Gelişiminiz için Seçmeli İkinci Yabancı Dil Olarak Rusçayı Tercih Ettiniz?" Sorusuna Göre Cevap Dağılımı

\begin{tabular}{|c|c|c|c|c|c|}
\hline & & Frequency & Percent & Valid Percent & $\begin{array}{l}\text { Cumulative } \\
\text { Percent }\end{array}$ \\
\hline \multirow[t]{7}{*}{ Valid } & $\begin{array}{l}\text { Daha önceden biraz Rusça } \\
\text { biliyor olmam }\end{array}$ & 2 & 7,7 & 7,7 & 7,7 \\
\hline & $\begin{array}{l}\text { Turizm sektöründe Rusçanın } \\
\text { (MYO'da alternatif ikinci y. } \\
\text { dil olan) Almancadan daha } \\
\text { popüler olduğu düşüncesi }\end{array}$ & 7 & 26,9 & 26,9 & 34,6 \\
\hline & $\begin{array}{l}\text { Günümüzde Turizm } \\
\text { sektöründe Rusça bilen } \\
\text { elemana daha çok rağbet } \\
\text { edilmesi }\end{array}$ & 6 & 23,1 & 23,1 & 57,7 \\
\hline & $\begin{array}{l}\text { Ruslara karşı özel } \\
\text { hayranlığım }\end{array}$ & 1 & 3,8 & 3,8 & 61,5 \\
\hline & $\begin{array}{l}\text { Rus toplumunu daha } \\
\text { yakından tanıma isteği }\end{array}$ & 2 & 7,7 & 7,7 & 69,2 \\
\hline & Tamamen keyfi & 8 & 30,8 & 30,8 & 100,0 \\
\hline & Total & 26 & 100,0 & 100,0 & \\
\hline
\end{tabular}

Tablo 8'de mesleki gelişimleri açısından ikinci yabancı dil olarak Rusçayı tercih etme nedenleri hakkında sorulan soruda öğrenciler arasında \% 7,7'sinin daha önceden Rusça ön bilgisi olduğu ortaya çıkmıştır. Bu gruba giren öğrencilerin Rusça bilgilerini akademik anlamda geliştirmek niyetiyle bilinçli olarak ikinci yabancı dil yelpazesi arasından Rusçayı seçtiği sonucuna varılabilir. \% 26,9'luk öğrenci grubu ise Turizm sektöründe Rusçanın Almancadan daha popüler olduğunu düşündüğünü belirtmiştir, bu nedenle de önerilen ikinci yabancı diller arasında Almanca yerine Rusçayı seçtikleri anlaşılmaktadır. Öğrencilerin \% 23,1'i günümüz şartlarında Turizm sektöründe 
Rusça bilen elemana daha fazla rağbet olduğu yönündeki inançları nedeniyle bu dersi seçmiştir. \% 3,8 oranındaki anket katılımcısı öğrenci Ruslara karşı özel sempati duyması nedeniyle, \% 7,7'sinin Rusları daha yakından tanıma arzusuyla, \% 30,8'inin ise bu dersi tamamen keyfi nedenlerle seçtiklerini bildirmesinden anlaşıldığı üzere öğrencilerin \% 42,3'ü ikinci yabancı dil olarak Rusça dersini bilinçsiz ve amaçsızca seçmiştir. Verilere göre \% 57,7'lik öğrenci kitlesi mesleki gelişimleri konusunda Rusçanın ikinci yabancı dil statüsünde gerekliliği bilinciyle ders seçimi yapmıştır.

Tablo 9: “Çevrenizdeki Kişilerle Rusça İletişim Kurabiliyor musunuz?” Sorusuna Göre Cevap Dağılımı

\begin{tabular}{|l|r|r|r|r|}
\hline & Frequency & Percent & Valid Percent & \multicolumn{2}{c|}{$\begin{array}{c}\text { Pumulative } \\
\text { Valid }\end{array}$ Evet } & 1 & 3,8 & 3,8 & 3,8 \\
Biraz & 13 & 50,0 & 50,0 & 53,8 \\
Aslinda iletişim & & & & \\
kurabileceğime inaniyorum & 5 & 19,2 & 19,2 & 73,1 \\
ama hata yapmaktan & & & & \\
korkuyorum & 7 & 26,9 & 26,9 & 100,0 \\
Hiç & 26 & 100, & 100,0 & \\
Total & 0 & & \\
& & & & \\
\hline
\end{tabular}

Öğrencilere anketin üçüncü bölümünde ikinci yabancı dil Rusça ile ilgili okuma, yazma ve konuşma yetilerine ilişkin sorular yöneltilmiştir. Öğrencilere ilk olarak çevrelerindeki kişilerle Rusça iletişim kurup kuramadıkları sorulduğunda anket uygulamasına katılan öğrencilerin \% 50'si çevresindeki kişilerle (arkadaşları arasında, staj ortamında ya da yaz döneminde çalıştıkları iş yerlerinde) biraz Rusça iletişim kurabildiğini, \% 26,9'luk öğrenci grubu ise çevresindeki kişilerle "hiç" iletişim kuramadığını ifade etmiştir.

Tablo 10: "Çevrenizde Staj Yaptığınız Kurum ya da Kuruluşta, Sınıf Arkadaşlarınız Arasında ya da Bulunduğunuz Tatil Yörelerinde Rusça Konuşulduğunda Konuşmanın Ne Hakkında Olduğunu ve/veya Söylemlerini Anlayabiliyor musunuz?" Sorusuna Göre Cevap Dağılımı

\begin{tabular}{|ll|r|r|r|r|}
\hline & & & & Cumulative \\
& & Prequency & Percent & Valid Percent & \multicolumn{2}{c|}{ Percent } \\
\hline Valid & Kismen anllyorum & 8 & 30,8 & 30,8 & 30,8 \\
& Çoğunluğunu anliyorum & 2 & 7,7 & 7,7 & 38,5 \\
Sadece birkaç kelime ya da & 11 & 42,3 & 42,3 & 80,8 \\
cümle anlayabiliyorum & 5 & 19,2 & 19,2 & 100,0 \\
Hiç anlamiyorum & 26 & 100,0 & 100,0 & \\
Total & & & \\
\hline
\end{tabular}

Tablo 10'dan öğrencilerin bulundukları ortamda Rusça konuşulması halinde \% 42,3'ünün anladıklarının sadece birkaç kelime ya da cümleden ibaret olduğu, \% 19,2'sinin ise Rusça konuşmaları hiç anlamadıkları ortaya çıkmıştır. 
Tablo 11: "Rusça Tabela ve Döviz Yazılarını, Medya Organları Tarafından Hazırlanmış Yazılı Yayınları (Kitap, Dergi, Makale, Köşe Yazısı, Tanıtım Broşürleri vs.) ya da Gördügünüz Rusça Yazılmış Herhangi Metni Okuyabiliyor musunuz?” Sorusuna Göre Cevap Dağılımı

\begin{tabular}{|ll|r|r|r|r|}
\hline & & & & Cumulative \\
& Frequency & Percent & Valid Percent & \multicolumn{1}{c|}{ Percent } \\
\hline Valid & Evet & 4 & 15,4 & 15,4 & 15,4 \\
& Okuyorum ama tamamin & 14 & 53,8 & 53,8 & 69,2 \\
anlayamiyorum & 8 & 30,8 & 30,8 & 100,0 \\
Kiril alfabesini bilmiyorum & 26 & 100,0 & 100,0 & \\
Total & & \\
\hline
\end{tabular}

Tablo 11 öğrencilerin \% 15,4'ünün Rusça tabela ve döviz yazılarını, medya organları tarafından hazırlanmış yazılı yayınları (kitap, dergi, makale, köşe yazısı, tanıtım broşürleri vs) ya da gördükleri Rusça yazılmış herhangi bir metni okuyabildiğini, \% 53,8'inin bahse konu Rusça yazıları okuyabildiğini ancak tamamını anlayamadığını, göstermektedir.

Tablo 12: "Rusça Yazı Yazabiliyor musunuz?" Sorusuna Göre Cevap Dağılımı

\begin{tabular}{|c|c|c|c|c|c|}
\hline & & Frequency & Percent & Valid Percent & $\begin{array}{c}\text { Cumulative } \\
\text { Percent }\end{array}$ \\
\hline \multirow[t]{6}{*}{ Valid } & Evet & 13 & 50,0 & 50,0 & 50,0 \\
\hline & $\begin{array}{l}\text { Matbu harflerle } \\
\text { yazabiliyorum }\end{array}$ & 1 & 3,8 & 3,8 & 53,8 \\
\hline & $\begin{array}{l}\text { Okuyabiliyorum ancak } \\
\text { yazamiyorum }\end{array}$ & 1 & 3,8 & 3,8 & 57,7 \\
\hline & El yazısı bilmiyorum & 1 & 3,8 & 3,8 & 61,5 \\
\hline & $\begin{array}{l}\text { El yazısı yazarken bazen } \\
\text { harfleri karıştırıyorum }\end{array}$ & 10 & 38,5 & 38,5 & 100,0 \\
\hline & Total & 26 & 100,0 & 100,0 & \\
\hline
\end{tabular}

Rusça yazı yazabilme yetileri sorusuna öğrencilerin \% 50'si olumlu yönde net yanıt vermiştir. Diğer \% 50'lik gruptan ise Rusça yazı yazarken el yazısı kullanılması nedeniyle \% 38,5'inin Rusça harflerin el yazısındaki karşılıklarını bilse dahi zaman zaman harfleri karıştırdığı anlaşılmaktadır.

Tablo 13: "Rusçada En Çok Sizi Zorlayan Aşağıdakilerden Hangisidir?” Sorusuna Göre Cevap Dağglımı

\begin{tabular}{|c|c|c|c|c|c|}
\hline & & Frequency & Percent & Valid Percent & $\begin{array}{c}\text { Cumulative } \\
\text { Percent }\end{array}$ \\
\hline \multirow[t]{6}{*}{ Valid } & Kiril alfabesi & 6 & 23,1 & 23,1 & 23,1 \\
\hline & $\begin{array}{l}\text { Kelimelerin vurgusu ve } \\
\text { telaffuzu }\end{array}$ & 7 & 26,9 & 26,9 & 50,0 \\
\hline & Okuma & 1 & 3,8 & 3,8 & 53,8 \\
\hline & Gramer & 6 & 23,1 & 23,1 & 76,9 \\
\hline & Konuşma & 6 & 23,1 & 23,1 & 100,0 \\
\hline & Total & 26 & 100,0 & 100,0 & \\
\hline
\end{tabular}

Tablo 13’te ikinci yabancı dil olarak Rusça öğrenim sürecinde öğrencilerin \% 26,9'unun kelimelerin vurgu ve telaffuzunu öğrenmede güçlük yaşadığı tespit edilmiştir. Geri kalan yanıtlar 
arasında eşit bir dağılım olmamakla birlikte öğrencilerin Kiril alfabesini öğrenmede, okumada, Rusça gramer kurallarını öğrenmede ve Rusça konuşmada zorlandıkları görülmüştür.

Tablo 14: "Rusça derslerinizde sizi en çok cezbeden şey nedir?" sorusuna göre cevap dağılımı

\begin{tabular}{|c|c|c|c|c|c|}
\hline & & Frequency & Percent & Valid Percent & $\begin{array}{c}\text { Cumulative } \\
\text { Percent }\end{array}$ \\
\hline \multirow[t]{4}{*}{ Valid } & $\begin{array}{l}\text { Yeni bir dil öğrenme } \\
\text { heyecanı }\end{array}$ & 18 & 69,2 & 69,2 & 69,2 \\
\hline & $\begin{array}{l}\text { Kürtçe ile ortak ya da benzer } \\
\text { kelimelerin olması }\end{array}$ & 5 & 19,2 & 19,2 & 88,5 \\
\hline & $\begin{array}{l}\text { Öğrenci -öğretici } \\
\text { diyalogunun birebir olması }\end{array}$ & 3 & 11,5 & 11,5 & 100,0 \\
\hline & Total & 26 & 100,0 & 100,0 & \\
\hline
\end{tabular}

Tablo 14'e bakıldığında \% 69,2 oranında Rusça derslerinde öğrencilerin en çok dikkatini çeken ve motivasyonunu artıran faktörler arasında yeni bir dil öğrenme heyecanı ön plana çıkmaktadır.

Tablo 15: “Rusça Öğrenirken Sizi En Çok Kaygılandıran Nedir?” Sorusuna Göre Cevap Dağılımı

\begin{tabular}{|c|c|c|c|c|c|}
\hline & & Frequency & Percent & Valid Percent & $\begin{array}{l}\text { Cumulative } \\
\text { Percent }\end{array}$ \\
\hline \multirow[t]{6}{*}{ Valid } & $\begin{array}{l}\text { Okuma ve konuşma } \\
\text { esnasinda telaffuzda hata } \\
\text { yapmak }\end{array}$ & 11 & 42,3 & 42,3 & 42,3 \\
\hline & El yazısı yazamamak & 3 & 11,5 & 11,5 & 53,8 \\
\hline & $\begin{array}{l}\text { Doğru vurgu ve tonlama } \\
\text { yapamamak }\end{array}$ & 6 & 23,1 & 23,1 & 76,9 \\
\hline & $\begin{array}{l}\text { Arkadaşlarımdan geri kalmak } \\
\text { ve başarısız olmak }\end{array}$ & 5 & 19,2 & 19,2 & 96,2 \\
\hline & Tahtada alıştırma yapmak & 1 & 3,8 & 3,8 & 100,0 \\
\hline & Total & 26 & 100,0 & 100,0 & \\
\hline
\end{tabular}

Tablo 15'e bakıldığında ikinci yabancı dil olarak öğrencilerin Rusça öğrenme süreçlerinde en çok (\% 42,3'lük oranla) okuma ve konuşma esnasında telaffuz hatası yapma kaygısı taşıdığı saptanmıştır. Öğrencileri en az kaygılandıran durumun ise \% 3,8'lik oran ile tahtada alıştırma yapma olduğu anlaşılmıştır.

Tablo 16: "Haftada İki Saatlik Rusça Dersinin Mesleki Gelişiminiz için Yeterliliği Konusunda Ne Düşünüyorsunuz?" Sorusuna Göre Cevap Dağılımı

\begin{tabular}{|ll|r|r|r|r|}
\hline & & & & $\begin{array}{c}\text { Cumulative } \\
\text { Percent }\end{array}$ \\
\hline Valid & Yrequency & Percent & Valid Percent & \multicolumn{1}{c|}{3,8} \\
& Haftada en az 4 saat olmalı & 1 & 3,8 & 3,8 & 96,2 \\
& 24 & 92,3 & 92,3 & 100,0 \\
& Hiçbir fikrim yok & 1 & 3,8 & 3,8 & \\
& Total & 26 & 100,0 & 100,0 & \\
\hline
\end{tabular}

Anketin son bölümü öğrencilerin kendi yetilerinden bağımsız ikinci yabancı dile ilişkin çevresel faktörlerle ilgili soruları içermektedir. Mesleki gelişimleri açısından ikinci yabancı dil dersi için ayrılan haftada 2 saatlik sürenin yeterliliği konusundaki görüşleri sorulduğunda öğrencilerin 
tamamına yakınının yani \% 92,3'ünün ilgili dersin haftada en az 4 saat olması yönünde hemfikir olduğu görülmüştür.

Tablo 17: “İkinci Yabancı Dil Olarak Rusçayı Seçtiğiniz için Memnun musunuz?” Sorusuna Göre

\begin{tabular}{|ll|r|r|r|r|}
\hline & & & & Cumulative \\
& & Frequency & Percent & Valid Percent & \multicolumn{1}{c|}{ Percent } \\
\hline Valid & Memnunum & 22 & 84,6 & 84,6 & 84,6 \\
& 1 & 3,8 & 3,8 & 88,5 \\
& Memnun değilim & 3 & 11,5 & 11,5 & 100,0 \\
& Hem memnunum, hem de & 26 & 100,0 & 100,0 & \\
pişmanım & Total & &
\end{tabular}

Seçmeli ikinci yabancı dil yelpazesi içinden Rusça dersini seçtikleri için öğrencilerin bu kararlarından memnun olup olmadığı sorulduğunda Turizm sektörü ve Türkiye'ye gelen Rus turistler, çalışma olanakları gibi etkenleri göz önünde bulunduran öğrencilerden \% 84,6 oranında memnun olduklarına dair yanıt alınmıştır. Öğrencilerin \% 3,8'i ise ikinci yabancı dil olarak Rusça dersini seçmelerinden memnun olmadığını bildirmiştir.

Tablo 18: "Rusça Öğrenmeye Başladıktan Sonra Staj Yaptığınız Yerde Rus Turistlerle Diyalog Kurabildiniz mi?" Sorusuna Göre Cevap Dağılımı

\begin{tabular}{|c|c|c|c|c|c|}
\hline & & Frequency & Percent & Valid Percent & $\begin{array}{c}\text { Cumulative } \\
\text { Percent }\end{array}$ \\
\hline \multirow[t]{6}{*}{ Valid } & Evet & 1 & 3,8 & 3,8 & 3,8 \\
\hline & Hayır & 18 & 69,2 & 69,2 & 73,1 \\
\hline & Utandım & 1 & 3,8 & 3,8 & 76,9 \\
\hline & Hata yapmaktan çekindim & 2 & 7,7 & 7,7 & 84,6 \\
\hline & Biraz & 4 & 15,4 & 15,4 & 100,0 \\
\hline & Total & 26 & 100,0 & 100,0 & \\
\hline
\end{tabular}

Öğrencilerin okulda edindikleri Rusça bilgisini staj yerlerinde uygulama imkânı bulup bulamamalarına ilişkin soruya verilen yanıtlara bakıldığında öğrencilerin sadece \% 3,8'i olumlu yönde net yanıt verirken, yarısından fazlasının yani \% 69,2'sinin olumsuz yönde net yanıt verdiği görülmektedir. Ancak, bu durumun sebebi sorulduğunda öğrencilerin ders ve sinavlarının bitiş tarihinin turizm sezonunun erken başladığı tarihten çok sonraya denk gelmesi nedeniyle ağırlıklı olarak Rus turistlerin geldiği Akdeniz kıyıları dışında kalan henüz hizmet sektöründe eleman ihtiyacını tamamlayamamış otellere, ya da Akdeniz kıyılarında ancak Rus konuklarca tercih edilmeyen otellere staj başvurusu yapmak zorunda kaldıkları, dolayısıyla da bulundukları ortamda Rusça konuşma imkânı bulamadıkları gerçeği ortaya çıkmıştır. 
Tablo 19: "Staj Yaptığınız Yerde Rusça Biliyor Olmanız Size Mesleki Anlamda Avantaj Sağladı mı?" Sorusuna Göre Cevap Dağılımı

\begin{tabular}{|c|c|c|c|c|c|}
\hline & & Frequency & Percent & Valid Percent & $\begin{array}{c}\text { Cumulative } \\
\text { Percent }\end{array}$ \\
\hline \multirow[t]{4}{*}{ Valid } & $\begin{array}{l}\text { Mezun olduktan sonra staj } \\
\text { yaptığım yerde çalışabilme } \\
\text { imkânına sahip oldum }\end{array}$ & 5 & 19,2 & 19,2 & 19,2 \\
\hline & Hayır, hiçbir getirisi olmadı & 9 & 34,6 & 34,6 & 53,8 \\
\hline & $\begin{array}{l}\text { Rusçanın mesleki gelişimim } \\
\text { bakımından önemini } \\
\text { anlamamı sağladı }\end{array}$ & 12 & 46,2 & 46,2 & 100,0 \\
\hline & Total & 26 & 100,0 & 100,0 & \\
\hline
\end{tabular}

Tablo 19, staj yaptıkları yerlerde öğrencilerin Rusça bilmelerinin kendilerine mesleki anlamda avantaj sağlayıp sağlamadığına ilişkin soruya \% 46,2'lik bir grup öğrenci Rusçanın bireyin kendi mesleki gelișimi açısından önemini anlamasını sağladığına inandığı yönünde cevap vermişlerdir. Ancak bu sorunun yanıtları arasında öğrencilerin \% 34,6 değerinde Rusça bilmelerinin kendileri için hiçbir avantaj sağlamadığı yanıtını vermesi bir önceki soruya verilen yanıtları doğrular niteliktedir.

Tablo 20: "Kürtçe Bilen Bir Kişinin Rusça Öğrenebilme Kolaylığı Hakkında Ne Düşünüyorsunuz?" Sorusuna Göre Cevap Dağılımı

\begin{tabular}{|c|c|c|c|c|c|}
\hline & & Frequency & Percent & Valid Percent & $\begin{array}{c}\text { Cumulative } \\
\text { Percent }\end{array}$ \\
\hline \multirow[t]{5}{*}{ Valid } & $\begin{array}{l}\text { Her iki dilde de benzer } \\
\text { seslerin olması telaffuzu } \\
\text { kolaylaştırır }\end{array}$ & 12 & 46,2 & 46,2 & 46,2 \\
\hline & $\begin{array}{l}\text { Her iki dilde de cümle } \\
\text { vurgusunun benzerliği } \\
\text { öğrenmeyi kolaylaştırır }\end{array}$ & 1 & 3,8 & 3,8 & 50,0 \\
\hline & $\begin{array}{l}\text { İki dildeki benzer kelimeler } \\
\text { öğrenmeyi kolaylaştırır }\end{array}$ & 5 & 19,2 & 19,2 & 69,2 \\
\hline & $\begin{array}{l}\text { Akılda kalıcı olmasını sağlar } \\
\text { ve çağrışım yaparak } \\
\text { hatırlamaya yardımcı olur }\end{array}$ & 8 & 30,8 & 30,8 & 100,0 \\
\hline & Total & 26 & 100,0 & 100,0 & \\
\hline
\end{tabular}

Anketin ikinci ve üçüncü bölümünü bütünlemesi bakımından Tablo 20'de öğrencilere Kürtçe bilen bir kişinin Rusça öğrenebilme kolaylığı hakkındaki düşünceleri sorulmuş ve alınan cevaplardan öğrencilerin \% 46,2'sinde her iki dilde de benzer seslerin olmasının telaffuzu kolaylaştırdığı, \% 3,8'inde her iki dilde de cümle vurgusunun benzer olmasının öğrenmeyi kolaylaştırdığı, \% 19,2' sinde iki dildeki benzer kelimelerin olmasının öğrenmeyi kolaylaştırıcı etkisi olduğu, \% 30,8'inde ise akılda kalıcı olmasını sağlamasının yanı sıra yaptığı çağrışımla hatırlamaya yardımcı olduğu kanaati oluştuğu anlaşılmıştır. 
Tablo 21: “Rusça Öğrenirken En Çok Zevk Aldığınız Etkinlik Nedir?” Sorusuna Göre Cevap Dağılımı

\begin{tabular}{|c|c|c|c|c|c|}
\hline & & Frequency & Percent & Valid Percent & $\begin{array}{c}\text { Cumulative } \\
\text { Percent }\end{array}$ \\
\hline \multirow[t]{5}{*}{ Valid } & Ödev yapmak & 5 & 19,2 & 19,2 & 19,2 \\
\hline & Monolog yapmak & 1 & 3,8 & 3,8 & 23,1 \\
\hline & Diyalog yapmak & 13 & 50,0 & 50,0 & 73,1 \\
\hline & Kelime ezberlemek & 7 & 26,9 & 26,9 & 100,0 \\
\hline & Total & 26 & 100,0 & 100,0 & \\
\hline
\end{tabular}

Tablo 21 öğrencilerin Rusça derslerinde yapmaktan en çok zevk aldığ etkinliği göstermektedir. Öğrencilerin \% 50'sinin en çok diyalog yapmaktan zevk aldığı tespit edilmiştir, geri kalan \% 50'lik grupta yer alan öğrenciler ise farklı oranlarda diğer etkinlikleri yapmaktan zevk aldığını belirtmiştir.

Tablo 22. "Rusça Okuyup Yazabilmek ve Konuşabilmek Size Kendinizi Nasıl Hissettiriyor?" Sorusuna Göre Cevap Dağılımı

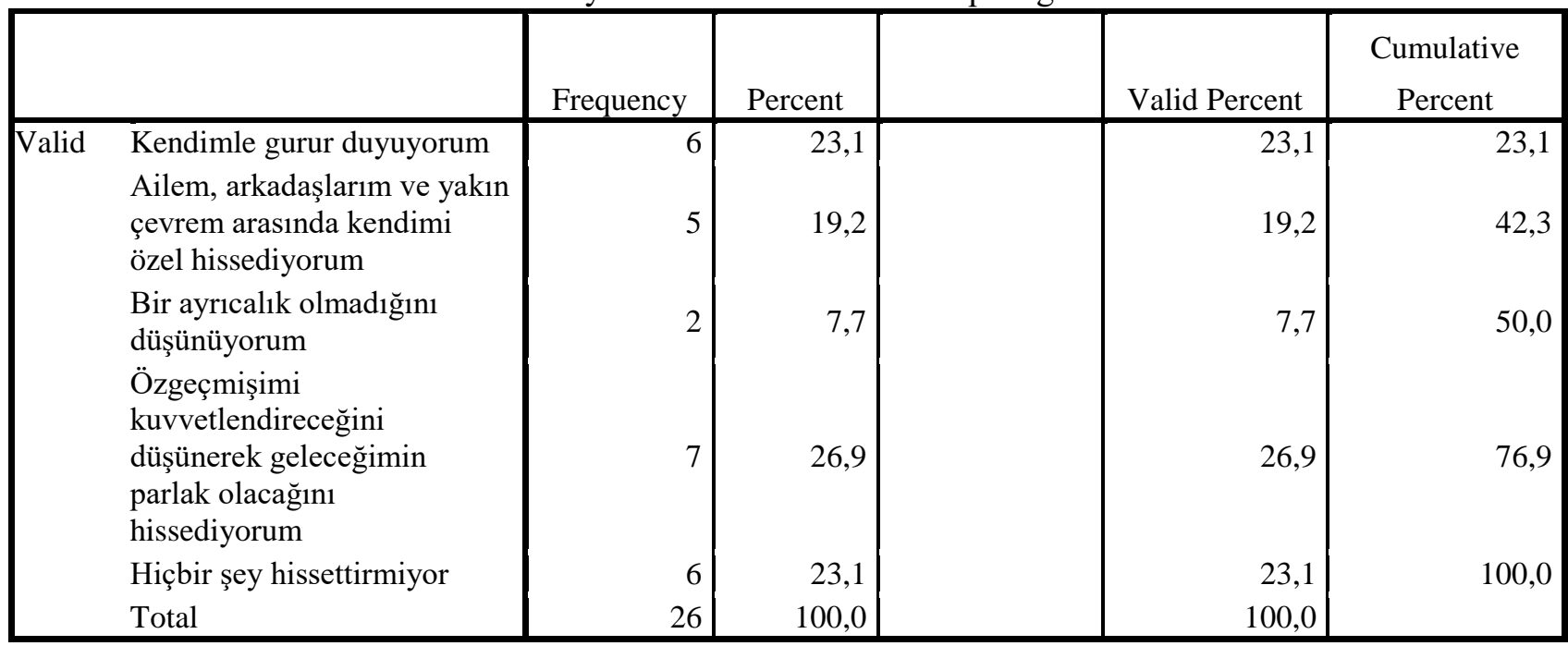

Anket çalışmasının son sorusunda öğrencilerin ikinci yabancı dil olarak Rusça edinimlerine ilişkin hisleri öğrenilmek istenmiştir. Verilen cevaplar arasında \% 7,7'lik bir grup bu durumun bir ayrıcalık olmadığını düşünmekteyken, katılımcıların ağırlıklı olarak, yani \% 26,9'unun yüksek öğrenimleri esnasında edindikleri Rusça bilgisinin özgeçmişlerini güçlendireceği düşüncesiyle geleceklerinin parlak olacağı hissinde oldukları gözlenmiştir.

\section{Sonuç ve Öneriler}

Bu araştırmada Van Yüzüncü Yıl Üniversitesi, Van Meslek Yüksek Okulu bünyesindeki Turizm ve Otel İşletmeciliği ve Turizm Rehberliği Programları'ndaki öğrencilerin özellikle de ana dili Kürtçe olan öğrencilerin ikinci yabancı dil olarak Rusça öğrenme motivasyonları araştırılmıştır. Toplam 26 öğrenciye 22 sorudan oluşan bir anket uygulanmıştır. Bahse konu anketin ilk üç sorusu bireylerin kişisel özelliklerini ortaya çıkarmaya, ikinci bölüm ana dili Kürtçe olan öğrencilerin ana dilleri ile ilgili hangi yetilere sahip olduklarını belirlemeye, üçüncü bölüm öğrencilerin ikinci yabancı dil olarak Rusça öğrenmeleri neticesinde edindikleri yetileri tespit etmeye yöneliktir, dördüncü ve son bölüm ise öğrencilerin kendi yetilerinden bağımsız ikinci yabancı dile ilişkin çevresel faktörlerle ilgili soruları içermektedir. 
Araştırma esnasında Öğrencilerin ana dili farklılıklarına göre ikinci yabancı dil Rusçayı ögrenme performansları arasında fark var midır?, Ana dili Kürtçe olan ögrencilerin ikinci yabancı dil olarak Rusçayı ögrenmesi diğer ögrencilerden daha mı kolaydır?, Ana dili Kürtçe olan öğrenciler ikinci yabanci dil konumundaki hedef dili mesleki iletişim dili olarak benimsemişler midir?, Ana dili Kürtçe olan ögrencilerin Rusçayı ögrenme motivasyonları diğer ögrencilerden daha mı yüksektir? ve Ö̈rrenciler seçmeli ikinci yabancı dil olarak Rusçayı tercih etikleri için memnun mudur? sorularına alınan yanıtlar değerlendirildiğinde;

Öğrencilerin ana dili farklılıklarının ikinci yabancı dil Rusçayı öğrenme performanslarını etkilediği görülmüştür. Ana dili Kürtçe olan bilingual öğrencilerin ikinci yabancı dil olarak Rusçay1 öğrenme motivasyonlarının diğer öğrencilerden yüksek olduğu, yani daha kolay öğrendikleri sonucuna varılmıştır. Dolayısıyla Kürtçe ses ve kelime benzerlikleri, kelime ve cümle vurgusu, sözdizimi gibi etkenlerin öğrencilerin Rusça öğrenme motivasyonlarını direkt olarak artırdığı kaçınılmaz bir gerçektir. Ancak müfredata göre haftada 2 saat uygulanan ikinci yabancı dil derslerinin en az haftada 2 saat teorik ve 2 saat uygulama olmak üzere 4 saate çıkarılması gerekliliği doğmuştur. Çünkü anket sorularına verilen cevaplara bakıldığında öğrencilerin birçoğunun mesleki anlamda kendilerine ikinci yabancı dil Rusçanın büyük oranda katkısı olmasına karşın, bulundukları staj ve sezonluk iş ortamlarında telaffuz ve vurgu hatası yapmaktan çekindikleri görülmektedir. Yani öğrenciler sınıf içinde \% 50 oranda diyalog kurmaktan zevk almaktayken yabancı turistlerle Rusça iletişim kurmaktan tedirgin olmakta, yeterince pratik yapma imkânı bulamadıkları için hata yapmaktan korkmaktadır. Bir diğer sorun ise öğrencilerin akademik takvimlerinin diğer fakülte ve yüksek okullarla aynı olmasıdır. Bu da öğrencilerin zaten Türkiye'nin doğusundan batısına ya da güneyine inmek için çok geç kaldıklarını, staj yapacakları yerleri yetilerine ve yabancı dil tercihlerine göre kendilerinin seçme ihtimalinin ortadan kalktığını, staj başvurusu yaptıkları kuruluşların ihtiyaçlarını çok önceden karşılamış olması nedeniyle kendilerine geri hizmetlerde staj imkânı sunulduğunu, dolayısıyla da edindikleri birinci ve ikinci yabancı dillerini kullanma imkânından yoksun olduklarını göstermektedir. Öğrencilerin anket çerçevesinde sorulara verilen cevaplarından ikinci yabancı dil konumundaki Rusçayı mesleki iletişim dili olarak kısmen benimsedikleri anlaşılmaktadır. Bu durumun sebebi bulundukları staj ve çalışma ortamlarında Rusçayı kullanacak yeterince imkân bulamamalarına bağlanabilir. Bu bağlamda müfredatın yeniden gözden geçirilerek haftalık ve yıllık ikinci yabancı dil ders dağılımlarında düzenlemeler yapılması öğrencilerin birinci yabancı dil dersi ile en azından eşit ders imkânına erişerek eşit düzeyde başarıya ulaşmasında önemli bir etken olacaktır.

Yapılan anket çalışması verileri doğrultusunda öğrencilerin ikinci yabancı dil olarak Rusçayı seçtikleri için memnun oldukları görülmüştür.

Birinci ya da ikinci yabancı dil edinim sürecinde karşılaştırma hem öğretici hem öğrenci tarafından sıklıkla başvurulan yöntemlerden biridir. Ancak bu yönteme ana dili de dâhil etmek öğrenmede verimliliği artırmaktadır. Ne yazık ki ana dil kullanımı yabancı dil öğretim yöntemlerinde tartışmalı bir konu olsa da literatürde her zaman göz ardı edilmiştir. Burada kastedilen dersin ana dilde işlenmesi değil, ana dil ile karşılaştırma yaparak söz konusu yabancı dilin öğretiminde yeni yöntem geliştirilmesidir. Bu konu ile ilgili olarak öğretici bulunduğu ortama, sınıfindaki öğrencilerinin kapasitesine, ilgi alanlarına, beklentilerine ve öğrenme güçlük ya da kolaylığına göre yeni yöntemler geliştirmek zorundadır diyebiliriz. Yapılan araştırmalar Türkiye'de yabancı dil öğretim yöntemlerini geliştirmeye yardımcı olacak ve başarıda istenilen düzeye ulaşılmasını sağlayacaktır. Netice itibariyle ana dil öğrencilerin beslendiği, birinci yabancı dil ise ana dil ve erek dil arasında köprü görevini yerine getiren dildir, daha sonra öğrenilecek bütün diller için ise kendisinden önceki her bir dil hem köprü hem beslendiği kaynak olacaktır diyebiliriz. 


\section{Kaynakça}

Akalın, S., Zengin, B. (2007). Türkiye'de halkın yabancı dil ile ilgili algıları, Journal of Language and Linguistic Studies, 3(1), 181-200.

Akpınar Dellal, N., Bora Günak, D. (2009). Çanakkale Onsekiz Mart Üniversitesi'nde ikinci yabancı dil olarak Almanca öğrenen öğrencilerin öğrenme motivasyonları, Dil Dergisi, s.143, 20-41, https://doi.org/10.1501/dilder_0000000105

Arak, H. (2006). İkinci yabancı dil olarak Almancanın öğrenilmesinde İngilizcenin ve karşılaştırmalı dilbilgisinin rolü, Erciyes Üniversitesi Sosyal Bilimler Enstitüsü Dergisi, 21(2), 205-216, https://doi.org/10.31592/aeusbed.472814

Aydın, S. (2006). İkinci dil olarak İngilizce öğrenimindeki başarı düzeyinin bazı değişkenlere göre incelenmesi, Atatürk Üniversitesi Sosyal Bilimler Enstitüsü Dergisi, 8(2), 273-285, https://doi.org/10.13159/susbid.35

Balcı, U. (2016). Anadolu Liselerinde ikinci yabancı dil olarak Almanca eğitimi: Batman ili örneği, Dicle Üniversitesi Ziya Gökalp Eğitim Fakültesi Dergisi, s.29, 346-355, https://doi.org/10.14582/duzgef.757

Can, E., Can, C. I. (2014). Türkiye'de ikinci yabancı dil öğretiminde karşılaşılan sorunlar, Trakya Üniversitesi Eğitim Fakültesi Dergisi, 4(2), 43-63, https://doi.org/10.1501/egifak_0000000764

Demirel, M. (2012). Üniversite öğrencilerinin kullandıkları dil öğrenme stratejileri, Hacettepe Üniversitesi Eğitim Fakültesi Dergisi, 43, 141-153, https://doi.org/10.17679/inuefd.296138

Hanbay, O. (2013). Anadolu Lisesi öğrencilerinin cinsiyet değişkenine göre ikinci yabancı dil olarak Almanca dersinde bağımsız öğrenme düzeyleri, Uşak Üniversitesi Sosyal Bilimler Dergisi, 6(4), 271-280, https://doi.org/10.12780/uusbd196

Koçak, M., Çobanoğulları, F. (2017). Dünyada ikinci yabancı dil olarak Almanca öğretiminde Danimarka örneği, Maarif Mektepleri Uluslararası Eğitim Bilimleri Dergisi, 1(1), 1-12, https://doi.org/10.14582/duzgef.757

Küzeci, D. (2015). Yabancı dil seçimi ve yabancı dil politikaları, Kazım Karabekir Eğitim Fakültesi Dergisi, s. 30, 13-26, https://doi.org/10.19171/uuefd.29695

Memiş, M.R. (2018). Kelime hazinesi ve yabancı dilde kelime öğretimi üzerine, Turkish Studies International Periodical for the Languages, Literature and History of Turkish or Turkic, 13(19), 1273-1289, https://doi.org/10.7827/turkishstudies.13857

Mesbah, S.B. (2013). İkinci yabancı dil olarak Almanca seçen öğrenciler diyor ki: seviyorum, sevmiyorum, Hacettepe Üniversitesi Eğitim Fakültesi Dergisi, 28(2), 293-307, https://doi.org/10.14582/duzgef.757

Oruç, Ş. (2016). Türkçede ana dil ve ana dili, Journal of Turkish Language and Literature, 2(1), 311 322, https://doi.org/10.20322/lt.15463

Şevik, M. (2007). Yabancı dil sınıflarında anadilin yeri, Ankara Üniversitesi Eğitim Bilimleri Fakültesi Dergisi, 40(1), 99-119, https://doi.org/10.1501/egifak_0000000167

https://sozluk.gov.tr/ (Erişim T. 30.12.2019). 